\title{
NEW APPROACHES OF REGIONAL POLICY AS A SUPPORTING FACTOR OF THE SOCIOECONOMIC DEVELOPMENT OF THE REGION

\author{
Viktor Šoltés ${ }^{1}$, Katarína Repková Štofková ${ }^{2}$, Filip Lenko ${ }^{3}$
}

\begin{abstract}
Increasing economic growth and employment, as well as improving the quality of life of the population, is one of the priorities of each country. One of the options to achieve these goals is to balance regional disparities. In the current globalization process, balancing regional disparities is all the more important. The European Union, as one of the most important communities of states, seeks to reduce regional disparities within the Community through a cohesion policy. The Slovak Republic, as one of the member states of the European Union, seeks to support the least developed regions through incentives and grants. Because of this, it analyzes the situation in the regions, identifies the least developed regions and takes measures to support them. This article deals with the socio-economic analysis of the least developed regions and analyzes the measures that are taken to support them. The results of the article can be used by public authorities when planning other activities that are expected to have a positive impact on regional development.
\end{abstract}

JEL Classification Numbers: R11, R58, DOI: 10.12955/cbup.v7.1377

Keywords: Regional development, regional policy, support, socioeconomic development.

\section{Introduction}

A number of aspects have an impact on improving the quality of the population. The central state authorities aim to stimulate the growth of living standards. One of the tools for raising living standards is also balancing regional disparities through different measures. Because of this, the state authorities analyze the socio-economic situation in the regions on the basis of selected indicators. The aim is to select the least developed regions, propose appropriate measures for them and provide them with funding for realizing measures. This support can reduce unemployment, increase wages, increase purchasing power and thereby reduce regional disparities.

\section{Regional development}

As Výrostová (2010) writes, a region is a certain demarcated area that can be only defined depending on the purpose of the definition. The bases of regions are their geographical determination from which different types of regions can be derived. For example, it is an urban region, a social region or an economic region. In the narrower sense, regions can be classified into administrative and natural regions. As Šoltés and Štofková (2016) writes, natural regions were created in the context of the historical, natural formation of the Earth's surface. To a large extent, they were also influenced by living standards, settlement, and degrees of urbanization, socio-demographic characteristics and other aspects.

From the state administration and local government point of view, administrative regions are important. According to Lednický (2003), the administrative regions are formed by the subdivision of the country into smaller territorial units (from above), they must completely cover the entire territory of the country and they are always represented by the competent authorities. In the Slovak Republic, the administrative regions are legally regulated in Act no. 221/1996 Coll. on territorial and administrative organization of the Slovak Republic, as amended. This Act is based on the fourth head of the Constitution of the Slovak Republic and states that the administrative units of the Slovak Republic are regions and districts.

In addition to the above mentioned Act no. 221/1996 Coll. the regions are also covered by Act no. 539/2008 Coll. on support for regional development, as amended. It defines the region as a territorial unit defined according to The Nomenclature of Territorial Units for Statistics (NUTS) (fr. La Nomenclature des Unités Territoriales Statistiques). It is a hierarchical division of the country into territorial units, which was introduced by Eurostat for the European Union member states in 1988. This classification is currently regulated by the Regulation of the European Parliament and of the Council no. 1059/2003. The NUTS consist of at least three regional levels - NUTS 1, NUTS 2 and NUTS 3, aiming to provide comparable regional statistics data within the European Statistical System. Štofková and Stofko (2016) point out that in the Slovak Republic this classification is determined by the Decree

\footnotetext{
${ }^{1}$ University of Žilina, Faculty of security engineering, Žilina, Slovakia, Viktor.Soltes @ fbi.uniza.sk

${ }^{2}$ University of Žilina, Faculty of operation and economics of transport and communications, Žilina, Slovakia, Katarina.Repkova@fbi.uniza.sk.

${ }^{3}$ University of Žilina, Faculty of security engineering, Žilina, Slovakia, Filip.Lenko@fbi.uniza.sk.
} 
of the Statistical Office of the Slovak Republic no. 438/2004 Coll. The NUTS classification in Slovakia consists of three regional and two local levels.

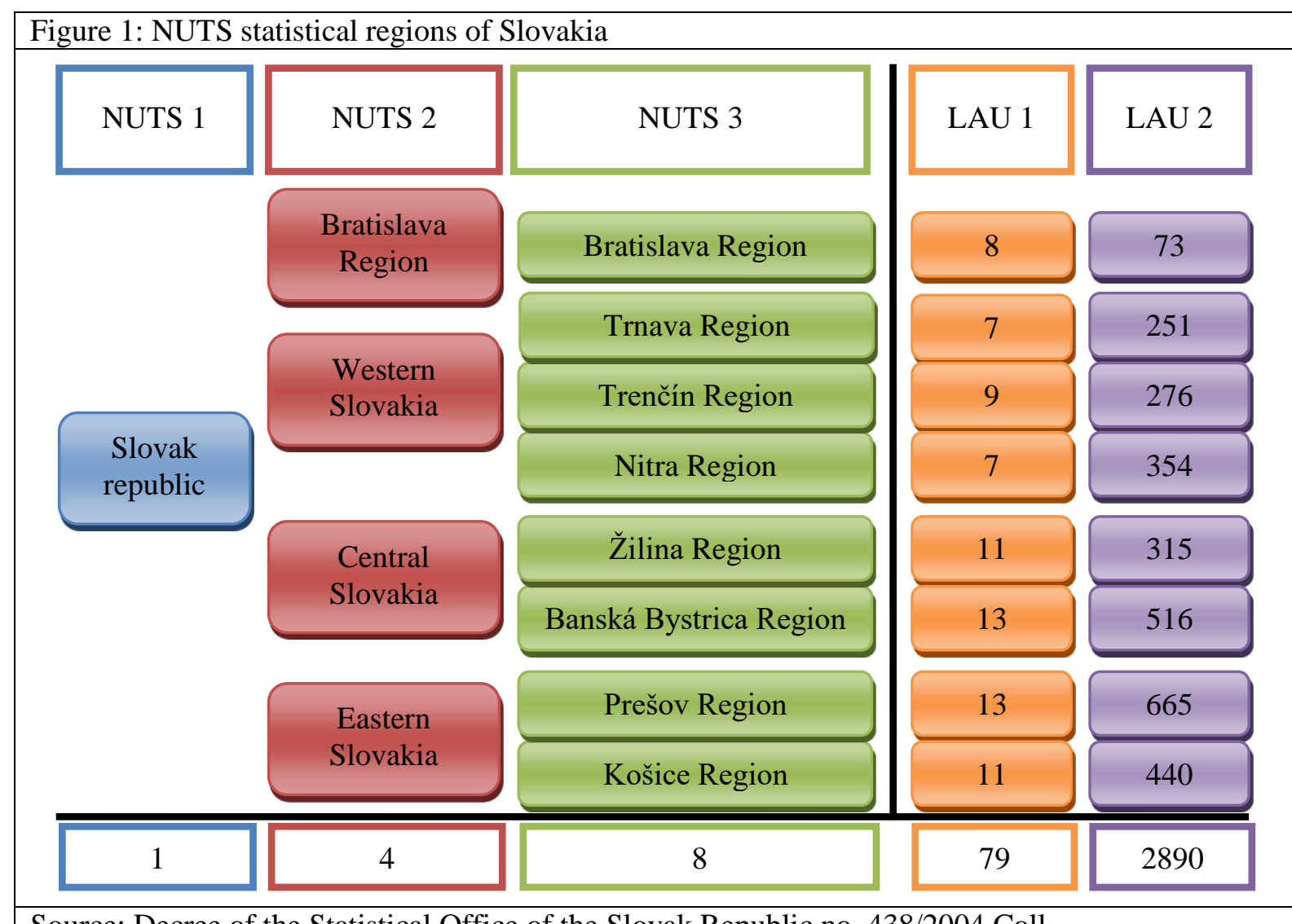

Source: Decree of the Statistical Office of the Slovak Republic no. 438/2004 Coll.

Ivaničková (1998) says, that according to the degree of economic development, regions can be divided into problem regions and developed regions. According to Buček et al. (2010) the problem regions can be further differentiated according to the reasons for their stagnation into structurally disadvantaged (originally developed regions, but at present their main sectors are depressed) and lagging behind (longterm uninteresting for investments) regions.

Maier and Tödtling (2006) writes, that from a regional policy point of view, regional development can be defined as a systematic process of positive change, which draws on the regions' individual ability to produce comparative advantages and exploits the resources that the region has and is equipped with. Šoltés et al. (2016) defines regional development as a set of social, economic, cultural and environmental processes and relations that take place in the region and which contribute to increasing its competitiveness, sustainable economic, social and territorial development and contribute to balancing economic and social differences among regions according to the NUTS classification.

\section{Selection of least-developed regions}

As mentioned above, the key Act in terms of regional policy in Slovakia is Act no. 539/2008 Coll. support for regional development, which sets out the objectives and conditions for the support of regional development. This Act also regulates the scope and competences of individual entities involved in activities related to regional development support. Such entities include the Government Office of the Slovak Republic, ministries and other central state administration bodies, higher territorial units and other territorial cooperation entities.

In addition to the Act on Regional Development, the Act no. 336/2015 Coll. on support to the least developed districts, as amended also covered support of regions on LAU 1 level (districts). For the purposes of this Act, the least developed district is the district registered in the list of the least developed districts. Municipalities, other legal entities and other territorial cooperation entities located in the territory of this district are supported in accordance with the Action Plan of the least developed district. The Action Plan is prepared by the Government Office of the Slovak Republic in cooperation with 
ministries, other central state administration bodies and the Central Office of Labour, Social Affairs and Family, which maintains and publishes a list of the least developed districts.

Lapšová (2018) writes, that the List of the least developed districts is created on the registered unemployment rate in the district. The district is included in the List, if during the nine quarters of the previous twelve consecutive years the registered unemployment rate was higher than 1.6 times as the average registered unemployment rate in the Slovak Republic. On 1 April 2018, in the amendment of the Act fell to 1.5 times the average rate of registered unemployment in Slovakia.

The District Office has a significant competence in the preparation of the Action Plan. If the district is included in the list of the least developed districts and therefore it is necessary to prepare an Action Plan, the District Office of this district prepares supporting documents for elaboration of an Action Plan, performs tasks and leads the agenda related to its realization. The Action Plan itself is approved by the Government of the Slovak Republic. According to Act no. 539/2008 Coll. the Action Plan contains:

- analysis of the adverse state of the district,

- assessing the development potential of the district,

- draft measures for its realization,

- time schedule,

- ways and sources of funding,

- elements for monitoring and evaluating progress.

The Action Plan is drawn up for a period of five years and the Government of the Slovak Republic must discuss it within nine months from the date, when the district was registered in the list of least developed districts. Figure 2 shows the development of the number of the least developed districts under Act no. 336/2015 Coll.

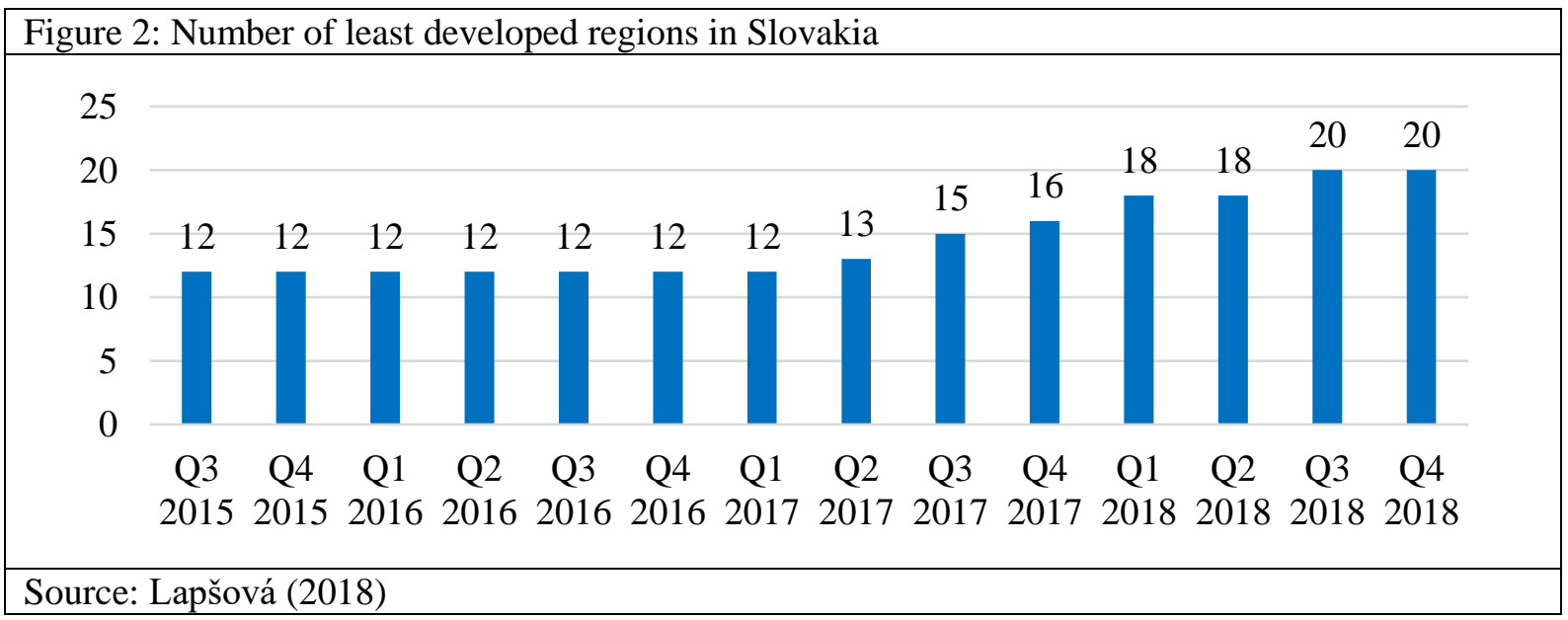

The analysis of the districts of the Slovak Republic under Act no. 336/2015 Coll. was conducted for the first time in 2015. Based on the prescribed criteria, 12 least developed districts were set. In 2017, the List was expanded to include 4 more districts. Similarly, 4 other districts have been added to the List in 2018. Currently, there are up to 20 least developed districts in Slovakia out of a total 79 districts. Despite the financial incentives and investment in development, none of the districts was removed from the list for that period.

As the unemployment rate is the only indicator of the least developed districts, it is necessary to monitor this indicator. Within the Slovak Republic, the unemployment rate has been decreasing for a long time. While at the beginning of the focused period (Q3 2015) the unemployment rate in Slovakia was 11.38 percent, at the end of 2018 (Q4 2018) the unemployment rate reached 5.04 percent. Figure 3 shows the development of the unemployment rate in 12 districts, which were first listed as the least developed districts.

Among the original least developed districts, the unemployment rate is highest in the district of Rimavská Sobota. The next three are the districts of Kežmarok, Rožňava and Revúca. Among these original 12 districts, the lowest unemployment rate in long-term is in the district of Vel'ký Krtíš and Lučenec. 


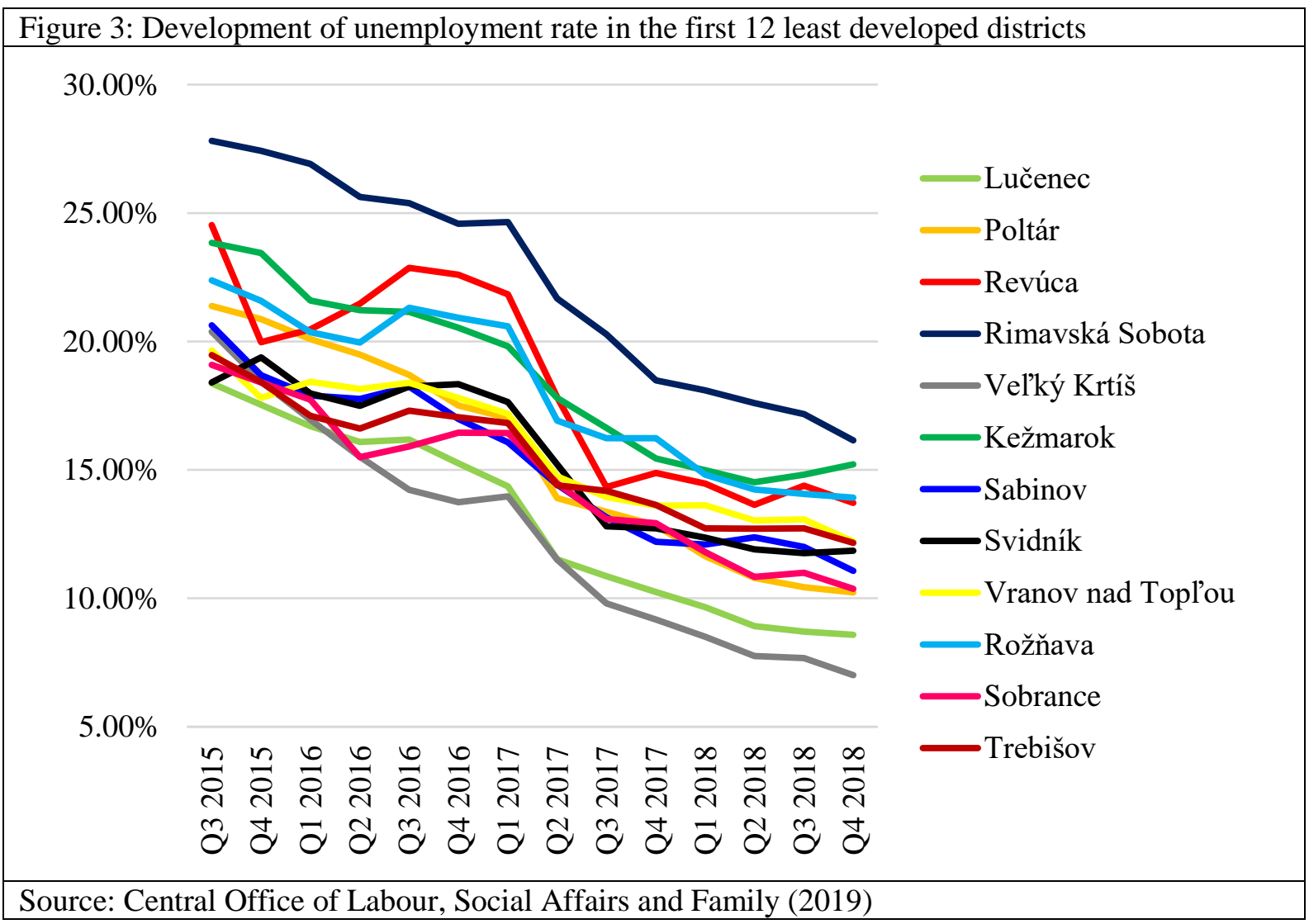

\section{Support of least-developed regions}

The least developed districts may, in line with the approved Action Plan, use tools such as the European Structural and Investment Funds advantage, more favorable conditions for obtaining investment incentives, or the possibility of drawing on regional contributions. All of these measures are primarily aimed for creating jobs. Support for the least developed districts should focus on the following priority areas within 5 years of the adoption of the Action Plan:

- development of regional and local economy,

- development of human capital through education for labor market needs,

- modern and available public services,

- infrastructure building,

- environmental care,

- development and promotion of tourism and restoration of cultural heritage.

Currently there are 20 districts in the List of the least developed districts. Since the latest two least developed districts (Michalovce district and Stropkov district) have been added to the list on the $19^{\text {th }}$ of October 2018, they do not have approved Action Plans until now, so it is not possible to set the amount of funds allocated to support them. It is also not possible to determine the number of work positions that will be created under the support.

Table 1 lists the 20 least developed districts with the date of their entry in this list and the population of these districts. In addition to these general information, Table 1 also contains information on the amount of financial support in the 2016-2020 period as well as the planned number of created work positions under this financial support. The last column of the table shows the amount of money spent for one work position creation support.

In a total of 20 least developed regions live approximately 1.15 million people, representing approximately 20 percent of the whole population. More than 22,000 new jobs should be created in the 18 least developed regions for more than one million people in 2016-2020. The estimated budget for support for these least developed regions in this period is over $€ 1.5$ billion. These financial resources are intended primarily to support the various activities in the regions that will create new jobs. For this reason, it can be said that $€ 79,000$ will be spent on creating one new work position. However, the 
aforementioned amount of financial resources for the creation of one new work position will also bring with it the development of infrastructure, the improvement of the workforce qualifications, the arrival of new investors, as well as the improvement of the provided services.

Table 1: Basic informations about least developed districts

\begin{tabular}{|c|c|c|c|c|c|}
\hline District & $\begin{array}{c}\text { Date of } \\
\text { enrollment in } \\
\text { the list }\end{array}$ & $\begin{array}{l}\text { Number of } \\
\text { inhabitants }\end{array}$ & $\begin{array}{c}\text { Planned number } \\
\text { of created work } \\
\text { positions }\end{array}$ & $\begin{array}{l}\text { Estimated } \\
\text { budget }[€]\end{array}$ & $\begin{array}{l}\text { Expenditure } \\
\text { on the one } \\
\text { created work } \\
\text { position }[€]\end{array}$ \\
\hline Lučenec & 31.12 .2015 & 74.016 & 1.440 & 147.324 .000 & 102.308 \\
\hline Poltár & 31.12 .2015 & 21.767 & 750 & 98.584 .000 & 131.445 \\
\hline Revúca & 31.12 .2015 & 40.052 & 1.100 & 61.000 .000 & 55.455 \\
\hline \begin{tabular}{|l} 
Rimavská \\
Sobota \\
\end{tabular} & 31.12 .2015 & 84.518 & 2.300 & 157.000 .000 & 68.261 \\
\hline Vel'ký Krtîš & 31.12 .2015 & 44.212 & 822 & 75.000 .000 & 91.241 \\
\hline Kežmarok & 31.12 .2015 & 73.756 & 2.000 & 52.000 .000 & 26.000 \\
\hline \begin{tabular}{|l|} 
Sabinov \\
\end{tabular} & 31.12 .2015 & 59.694 & 1.115 & 79.797.000 & 71.567 \\
\hline Svidník & 31.12 .2015 & 38.845 & 1.418 & 63.000 .000 & 44.429 \\
\hline \begin{tabular}{|l} 
Vranov nad \\
Topl'ou
\end{tabular} & 31.12 .2015 & 80.497 & 2.545 & 123.000 .000 & 48.330 \\
\hline Rožňava & 31.12 .2015 & 62.515 & 1.345 & 108.914 .000 & 80.977 \\
\hline \begin{tabular}{|l|} 
Sobrance \\
\end{tabular} & 31.12 .2015 & 22.818 & 1.225 & 69.000 .000 & 56.327 \\
\hline Trebišov & 31.12 .2015 & 105.797 & 1.540 & 114.426 .000 & 74.303 \\
\hline Gelnica & 20.07 .2017 & 31.627 & 931 & 55.749 .100 & 59.881 \\
\hline \begin{tabular}{|l|} 
Bardejov \\
\end{tabular} & 20.10 .2017 & 77.742 & 1.370 & 169.026 .683 & 123.377 \\
\hline \begin{tabular}{|l|} 
Medzilaborce \\
\end{tabular} & 20.10 .2017 & 12.119 & 377 & 38.554 .000 & 102.265 \\
\hline Košice - okolie & 22.01 .2018 & 125.289 & 822 & 71.430 .000 & 86.898 \\
\hline Levoča & 25.04 .2018 & 33.668 & 515 & 34.203 .000 & 66.414 \\
\hline Snina & 25.04 .2018 & 36.610 & 582 & 76.103 .000 & 130.761 \\
\hline \begin{tabular}{|l|} 
Stropkov \\
\end{tabular} & 19.10 .2018 & 20.623 & - & - & - \\
\hline Michalovce & 19.10 .2018 & 110.713 & - & - & - \\
\hline TOTAL & - & 1.156 .878 & 22.197 & 1.594 .110 .783 & 78.902 \\
\hline
\end{tabular}

\section{Conclusion}

The development of the least developed regions is one of the key activities of development of individuals, but also of the whole society. As Butek and Štofková (2016) writes in the process of globalization and pooling of states in international organizations, regional disparities are being balanced. The European Union's regional policy, also called the cohesion policy, is aimed at all regions of the European Union and includes measures in the form of strategic investments to increase economic growth, employment and thus improve the quality of life. Thanks to this form of solidarity, people in the least developed regions of the European Union can take advantage of the opportunities that European Union membership brings to them.

As a member state of the European Union, the Slovak Republic is actively seeking to find ways to support the least developed regions within its own territory. Because of this, in 2008, the Slovak Republic adopted an Act on the promotion of regional development, which was followed in 2015 by the adoption of an Act on support for the least developed districts. These Acts have made it possible to analyze the regions in the area of development and set criteria for the selection of the least developed regions, respectively districts. The least developed districts were originally those districts in which, during the nine quarters of the previous twelve consecutive years, the registered unemployment rate was higher than 1.6 times the average registered unemployment rate. Since 1 April 2018, this threshold has been reduced to 1.5 times the average rate of registered unemployment in Slovakia.

Based on this, a list of the least developed districts was created in 2015 with 12 registered districts. However, in 2017 this list was expanded by 4 districts, and in 2018 by another 4 districts. The List is currently comprised of 20 districts, which occupy approximately 1.15 million inhabitants of Slovakia (approximately 20 percent of the population). Action plans to support the least developed regions have 
been approved by 18 districts by now. Under these districts, the estimated investment is over $€ 1.5$ billion which, among other things, is intended to bring about 22,000 new work positions.

\section{Acknowledgement}

This contribution was undertaken as parts of the research project VEGA 1/0768/19, VEGA 1/0755/18.

\section{References}

Act no. 221/1996 Coll. on territorial and administrative organization of the Slovak Republic.

Act no. 336/2015 Coll. on support to the least developed districts.

Act no. 539/2008 Coll. on support for regional development.

Buček, M., Rehák, Š., \& Tvrdoň, J. (2010). Regionálna ekonómia a politika [Regional economics and politics]. Bratislava, Slovakia: Wolters Kluwer.

Butek, M., \& Štofková, Z. (2016). Relocalisation Trends in the Context of Globalization. 2016 ISSGBM International conference on information and business management, Hong Kong: Singapore management and sports science institutes, 3338.

Central Office of Labour, Social Affairs and Family. (2019). Nezamestnanost' - mesačné štatistiky [Unemployment - monthly statistics]. Retrieved from https://www.upsvr.gov.sk/statistiky/nezamestnanost-mesacne-statistiky.html?page_id=1254

Constitution of the Slovak Republic.

Decree of the Statistical Office of the Slovak Republic no. 438/2004 Coll.

Ivaničková, A. (1998). Regionalizácia a priestorová organizácia regionálneho rozvoja [Regionalization and spatial organization of regional development]. Bratislava, Slovakia: University of economics in Bratislava

Lapšová, M. (2018). Od 19. októbra 2018 pribudli v zozname najmenej rozvinutých okresov 2 nové okresy [Since 19 October 2018, 2 new districts have been added to the list of least developed districts]. Retrieved from https://www.humanet.sk/spravy/od-19-oktobra-2018-pribudli-v-zozname-najmenej-rozvinutych-okresov-2-nove-okresy.

Lednický, V. (2003). Tvorba strategie územního celku [Creating a territorial unit strategy]. Ostrava, Czech Republic: VSB Technical of Ostrava.

Maier, G., \& Tödtling, F. (2006). Regional- und Stadtökonomik 1 [Regional and urban economics 1]. Wien, Austria: Springer-Verlag.

Office of the Deputy Prime Minister of the Slovak Republic for Investments and Informatization. (2019). Podpora najmenej rozvinutých okresov a regionálny rozvoj [Support of Least-Developed Districts]. Retrieved from https://www.nro.vicepremier.gov.sk/index.html.

Regulation of the European Parliament and of the Council no. 1059/2003.

Šoltés, V., Repková Štofková, K., \& Kutaj M. (2016). Education as a regional development aspect. Edulearn16 proceedings, Barcelona, Spain: IATED Academy, 3643-3647.

Šoltés, V., \& Štofková, Z. (2016). Selected aspects of financing regional development in terms of self-government.

Marketing identity: brands we love - part II. Trnava, Slovak republic: Faculty of Mass media Communication, University of Ss. Cyril and Methodius, 453-460.

Štofková, Z., \& Štofko, S. (2016). Some indicators of quality of life in a globalized world. Globalization and its socioeconomic consequences 2016, Rajecké Teplice, Slovakia: University of Žilina, 2127-2134.

Výrostová, E. (2010). Regionálna ekonomika a rozvoj [Regional economy and development]. Bratislava, Slovakia: Wolters Kluwer. 